\title{
THE RISE AND FALL OF TURLOUGH TYPOLOGIES: A CALL FOR A CONTINUUM CONCEPT
}

\author{
Marjolein Visser ${ }^{1, *}$, Eugenie Regan ${ }^{1,2}$, James Moran ${ }^{1,2,3}$, Mike Gormally ${ }^{1}$, and Micheline Sheehy Skeffington ${ }^{2}$ \\ ${ }^{1}$ Centre for Environmental Science \\ National University of Ireland, Galway \\ Galway, Ireland \\ ${ }^{2}$ Department of Botany \\ National University of Ireland, Galway \\ Galway, Ireland \\ ${ }^{3}$ Present Address: \\ Teagasc Research Centre, \\ Athenry, Co. Galway, Ireland \\ *Address for correspondence: \\ Eco-Innovation, 11 Ashe Road \\ Shantalla, Galway, Ireland \\ E-mail: Marjolein.visser@eco-innovation.net
}

\begin{abstract}
Turloughs are seasonal ground-water-dependent wetlands that occur in the karst landscape of western Ireland. Various typologies based on between-site variation have been applied to turloughs. However valid in understanding turlough functioning, these typologies are difficult to relate to one another, tend to overlook within-site variation, and do not address management issues affecting these priority habitats of the European Union. Furthermore, typologies have not fully utilized available data and lack the comprehensive perspective needed to capture processes driving turlough ecology. We used unpublished and published data on a per-turlough basis to explore the main variables affecting turlough ecology in Ireland. Multivariate analysis shows that turloughs do not split into distinct types; rather, there is one continuum from dry to wet sites, which affects all aspects of turlough ecology. This dry-wet continuum arises from various degrees of karstification of the underlying and surrounding bedrock, which in turn leads to different water inputs, water chemistries, and different deposits on the turlough floor. Few turloughs can be considered as truly dry or wet; most are intermediate or dry-wet mosaics. Turloughs or parts of turloughs at extremes of the dry-wet continuum need different protection measures to prevent water pollution, manage summer grazing, or maintain the hydrologic regime. Although turlough typologies seem logical and straightforward in theory, in practice, typing turloughs is difficult. Trying to fit turloughs within typologies that are weakly supported by the data on which they are based can lead to problems if inappropriately used. A dry-wet continuum concept not only better fits these same data but also gives scope for a more flexible approach to turlough conservation.
\end{abstract}

Key Words: karst, Ireland, non-metric multidimensional scaling, turloughs, wetlands

\section{INTRODUCTION}

\section{Capturing Wetland Diversity}

There are many reviews of wetland ecology to be found, each one with a different classification of wetland types (Westlake et al. 1998, Batzer et al. 1999, Keddy 2000, Haslam 2003). While reflecting the complexities of wetland ecology, it makes conservation and management objectives sometimes difficult to implement. Recently, an alternative to classifying wetlands was provided by Euliss et al. (2004) by suggesting to work instead with a wetland continuum concept. It provides a framework to understand the variability in biological communities of any given wetland by looking at its abiotic setting in the first place and allowing for temporal variations due to climate variability. In this paper, the best available data on a specifically Irish type of wetland, turloughs, are analyzed to compare existing turlough typologies with a continuum concept derived from that analysis. 


\section{Turloughs}

Turloughs are areas seasonally flooded by karst ground water with sufficient frequency and duration to produce soils and/or ecological communities characteristic of wetlands. The most common translation of the Irish 'turlough' is 'dry lake,' but a different interpretation of the suffix 'lough' can lead to 'dried up spot' (Joyce 1869). Either way, the name demonstrates the ephemeral nature of turloughs. They are one of the main karstic features of the Carboniferous limestone landscape in the west of Ireland. Other features include swallow holes, sinking streams, sparse or intermittent streams, limestone pavement, dry valleys, caves, and large springs (Drew and Daly 1993). Turloughs normally fill and empty through underground passages and estavelles (sinkholes that can also act as springs), but some also have inflowing rivers and streams. They generally flood in winter and dry out in summer, but there may be other sporadic rises of water levels in response to high rainfall. Their main land use consists of summer grazing. The vegetation of turloughs is zoned in relation to flood duration (Goodwillie 1992). The plant communities are mainly small sedge, wet grassland, and aquatic communities (O'Connell et al. 1984, Goodwillie 1992). Turloughs contain unique aquatic and terrestrial invertebrate communities adapted to the temporal variation in water availability and edaphic conditions (Foster et al. 1992, Good and Butler 2001).

Coxon (1986) attempted the first comprehensive inventory of turloughs in Ireland and used the following hydrologic criteria to distinguish turloughs from other wetlands: (1) seasonal flooding with open water at least $0.5 \mathrm{~m}$ deep for part of the year and a dry floor for another part of the year and (2) emptying to ground water, evidenced by the lack of a natural surface outlet. There are a number of factors necessary for turlough formation. Coxon (1987a) mentions (1) well-jointed and bedded pure limestone and (2) less than a few meters of glacial deposit cover in the area, to which can be added (3) high rainfall, and (4) impeded drainage, either in the aquifer or in the turlough basin. There is, however, large variation in these factors, and this leads to wide variation in biological communities of turloughs.

\section{Typologies}

Wide variation among turloughs has led to the advancement of several turlough typologies (Table 1). The first mention of turlough types was by Williams (1970). He distinguished flash flooding upland turloughs from the more numerous lowland turloughs whose flooding is linked with the seasonality of the ground-water table. Some years later, Drew (1976) also distinguished two turlough types that were very similar to Williams (1970), although Drew's typology was in relation to the hydrology of one specific lowland area south-east of the town of Ballinrobe (Clare catchment, see Figure 1) and did not cite Williams (1970). Williams' upland type would therefore seem to exist in karst lowlands as well. Later authors produced typologies based on more systematic hydrologic and ecological studies of a broader range of turloughs. Consequently, the picture became more complex. MacGowran (1985) studied the vegetation of 15 turloughs in the Burren lowlands and uplands (Figure 1). Following Williams (1970), he distinguished two upland types and three lowland types. While MacGowran conducted an intensive study of a small number of turloughs in a small area, Coxon (1986) studied all turloughs $>10$ ha countrywide and was the first to underpin her typology with statistical analyses. Cluster analyses of a range of geomorphological, hydrologic, and vegetation parameters on 60 turloughs considered unaffected by artificial drainage led her cautiously to distinguish five different clusters (Coxon 1987b) when overlaid on a detrended correspondence analysis (DCA) plot. She pointed out, however, that only two clusters (4 and 5) clearly separate from the dense cloud of clusters 1,2 , and 3 . None of the statistical techniques used produced clearcut boundaries between clusters. Cluster 4 turloughs experience shallow flooding for brief periods and support flood-intolerant plant species. Cluster 5 coincides well with MacGowran's Gort type and with the later-defined 'riverine turloughs.' The term 'riverine turloughs' was introduced by the most elaborate turlough typologies to date of Southern Water/Jennings and O'Donovan (1997) and Goodwillie and Reynolds (2003). The former is based on work described in an unpublished report to the Office of Public Works of Ireland on all wetlands of the Gort area (Figure 1) in South Galway (Southern Water/Jennings and O'Donovan 1997). The report distinguishes riverine turloughs with a large throughput of water, hence large fluctuations (Types A and B), from turloughs with smaller catchments, hence moderate fluctuations. The latter are split again into turloughs that are either dry (types G, H and I) or wet (types E and F) during the growing season. The water-level fluctuations in types $\mathrm{C}$ and $\mathrm{D}$ are considered too small to call these sites turloughs (not added to Table 1). Goodwillie and Reynolds (2003) base their typology almost entirely on the previous one and group turloughs 
Table 1. Turlough typologies. The position of each type by different authors is related to a gradient from dry (left) to wet (right) and their positioning in respect of one another shows the overlap of the typologies. Author's examples (in italics) were limited to turloughs that occur at least twice in the table (for comparison) or belong to the group of nine turloughs mentioned in the text. Southern Water/Jennings and O'Donovan's (1997) C and D types are not turloughs but should be positioned to the right of Types E and F, under the heading 'Wet sites with summer water' (with small waterlevel fluctuations).

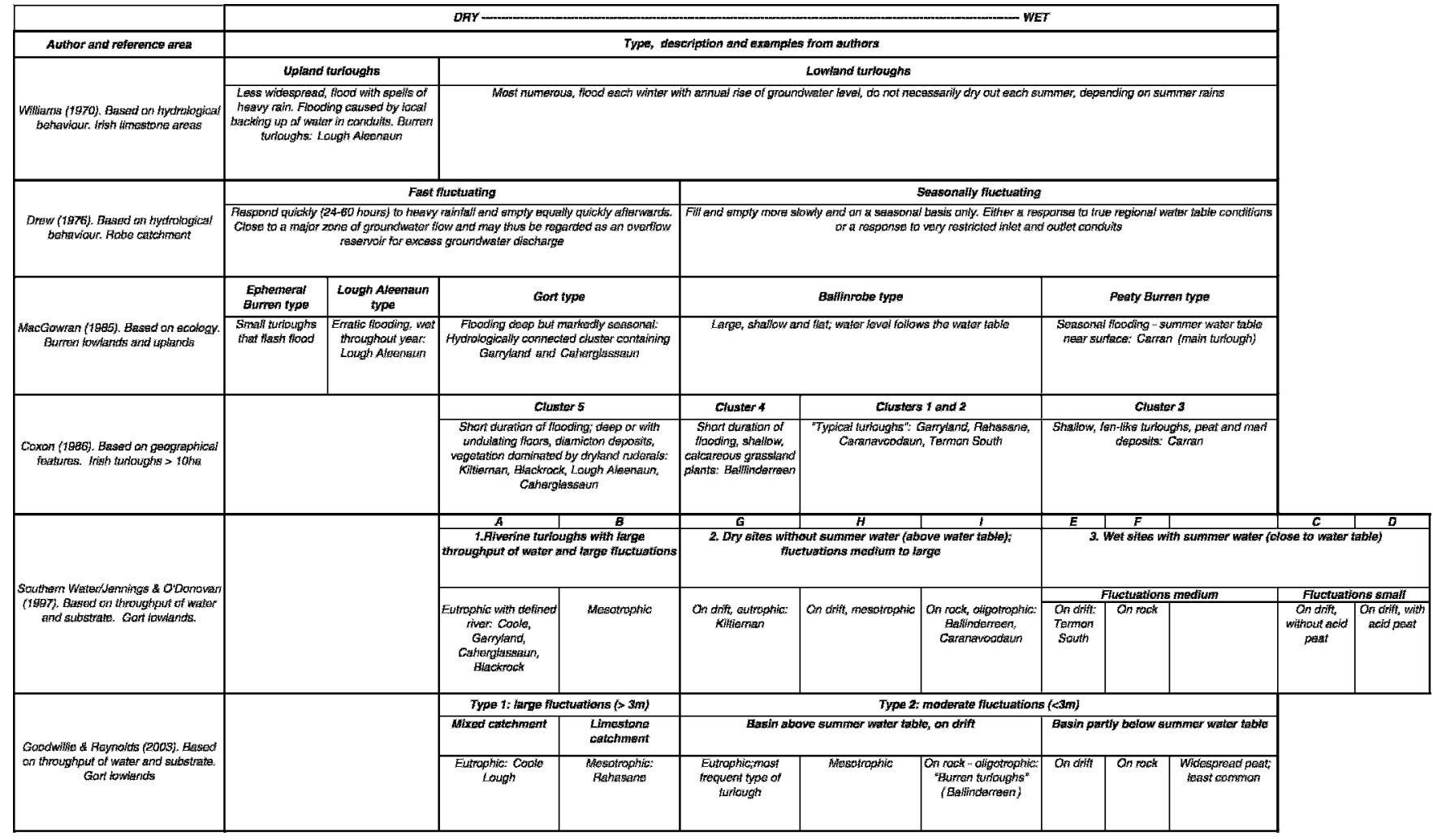

into Type 1 with large fluctuations and Type 2 with moderate fluctuations (Table 1). Both these typologies use mainly nutrient status to refine further the major types. Nutrient status is understood to vary either with the local turlough substrate (on glacial drift versus rock) or with the geology of the catchment of the turlough waters (mixed rock types versus limestone). Goodwillie and Reynolds (2003) also added a turlough type with widespread peat development that was not recognized among the Gort wetlands in the report of Southern Water/ Jennings and O'Donovan (1997).

Table 1 shows how the typologies relate to one another when tentatively matched on the basis of a dry-wet gradient. However, it is difficult to compare types, as different authors use diverse parameters to define their typologies. The match Gort type-Cluster 5 - riverine turloughs is the most obvious commonality between typologies. Williams' 'true' upland types were not considered by subsequent authors, and the loose match between other lowland types is mainly based on the summer water regime.
Testing the Case for a Dry-Wet Gradient

Wheeler and Proctor (2000) stated that most ecological and floristic variation within north-west European mire vegetation is accounted for by just three ecological gradients: $\mathrm{pH}$, availability of nitrogen and phosphorus, and water level. For turloughs, there are reasons to believe that these gradients are interdependent. So an alternative to working with turlough typologies that split up the variation according to various supposedly independent factors is to use one single gradient and to test whether this gradient can include other ecologically relevant factors. Coxon (1987b) suggested that the main DCA-axis would appear to arrange turloughs in order of duration of flooding, although this was not a variable as such in her analysis. In turn, duration and depth of flooding are considered the main ecological factors affecting turlough plant communities (Goodwillie 1992, Goodwillie and Reynolds 2003). Our paper will investigate whether duration of flooding yields a dry-wet gradient operating in the turlough system that encompasses 


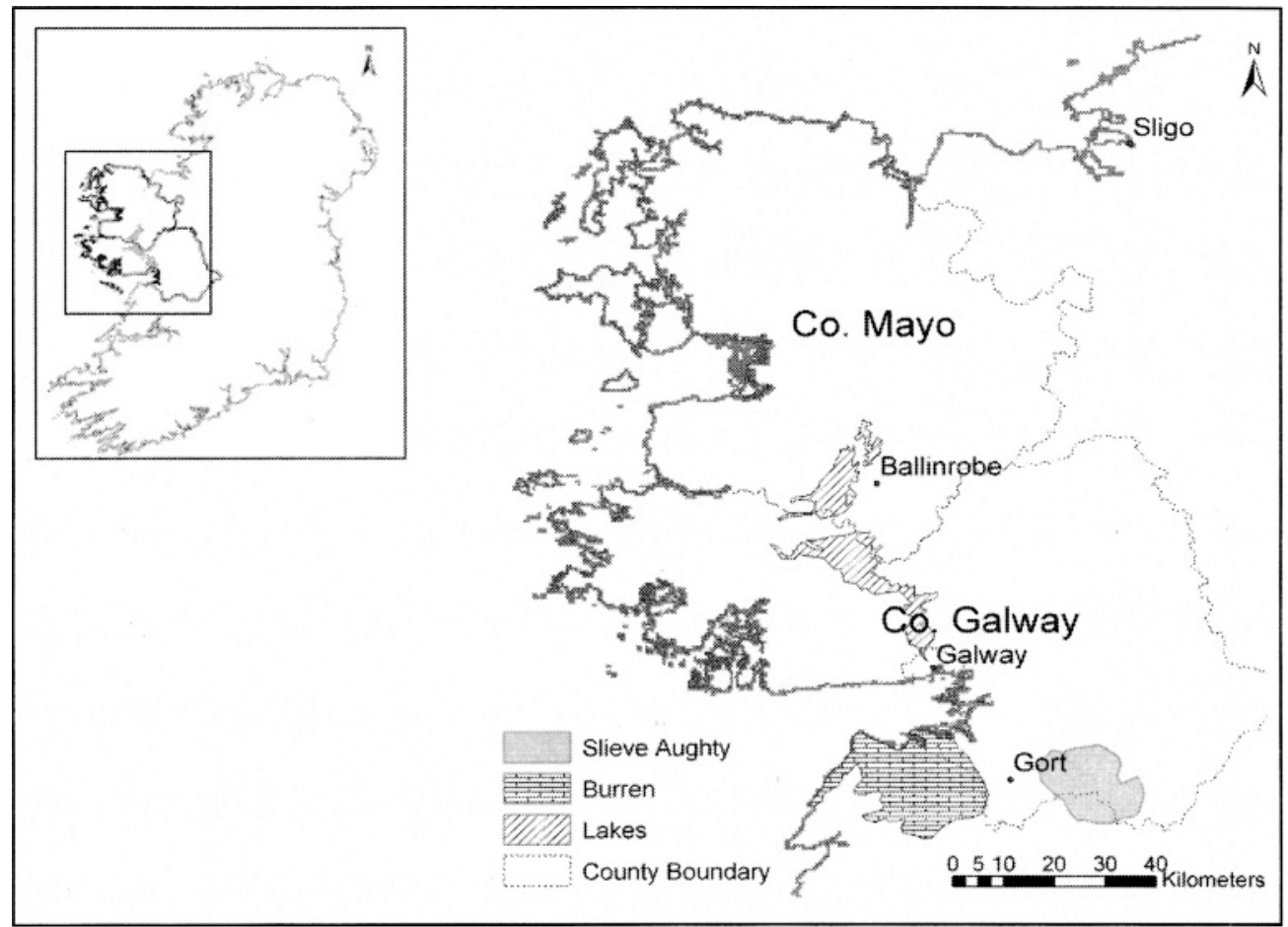

Figure 1. Map showing the location of the main turlough research areas in Ireland and adjacent lakes: the Robe catchment (South Co. Mayo) east of Ballinrobe and the Gort lowlands (South Co. Galway) in between the Burren plateau and Slieve Aughty mountains. The major towns are shown for reference.

other important ecological factors. The dry extreme is where the total time of flooding, or hydroperiod, is short (approx. three months or shorter) and the soils dry out quickly after the water recedes. The wet extreme is where the hydroperiod is long (approx. six months or longer) and the soils retain high moisture levels throughout the summer. Some turloughs contain permanent lakes. The turlough area is then defined as the area that floods during wet periods. Thus, both dry and wet extremes could have a lake at the center, the level of dryness referring only to the periodically flooded area.

The purpose of this paper is twofold. 1. Turloughs are listed as a priority habitat in Annex I of the 1992 European Union Habitats Directive (92/43/EEC). The Habitats Directive is the main piece of EU legislation with regard to wildlife conservation. It provides the basis for the designation of a EU-wide network of Special Areas of Conservation (SAC), consisting of Annex I habitats. This network of SACs along with the legislation behind it is commonly referred to as Natura 2000. Ireland, as all other EU-members, is obliged to maintain the favorable conservation status of Annex I habitats, especially priority habitats. Despite this obligation, the present understanding of the ecology and effective conservation of these habitats is limited because the available information is scattered and has never been collated. The first aim is therefore to compare the most recent typologies (based on retrievable data) with our dry-wet gradient hypothesis for their goodness-of-fit. For this comparison, we will use existing biological, hydrologic, and geomorphological data, published and unpublished. 2. Many hydrogeological features of turloughs remain enigmatic because they are part of a complex karst landscape that is poorly understood. This incomplete understanding of turlough functioning impedes management of turloughs for conservation. The second aim is to review the available literature on karst in relation to turloughs to help underpin ideas that result from the re-analysis of the existing data.

\section{MATERIAL AND METHODS}

To date, there are three unpublished data sources for comparing turloughs: Coxon (1986), Goodwillie (1992), and Southern Water/Jennings/O'Donovan (1997). Publications that draw on these sources are Coxon (1987b) and Goodwillie and Reynolds (2003) (Table 1). Out of these sources, two datasets were 
constructed for our analysis, hereafter called the 'Gort Dataset' and the 'Coxon/Goodwillie Dataset' (Table 2). The Gort dataset uses 11 variables (Table 2) of a total of 13 that were used to construct the typologies of Southern Water/Jennings and O'Donovan (1997) and Goodwillie and Reynolds (2003). They are listed in Southern Water/Jennings and O'Donovan (1997), which details all wetland sites (73 in total, turloughs and non-turloughs) in the Gort lowlands in the South-Galway and NorthClare area of Ireland, and were copied as such. Only those sites for which data were available for all variables (54 out of 73) were used in our analysis. The Coxon/Goodwillie Dataset combines variables from Coxon (1986), who surveyed all turloughs $>10$ ha in Ireland (90 sites in total), with variables from Goodwillie (1992), who surveyed the vegetation of the 61 turloughs that Coxon (1986) considered to be unaffected by drainage. A total of 10 variables were taken from Coxon (1986) and five from Goodwillie (1992) (Table 2). The 10 variables of Coxon (1986) are a subsample of a larger set she used to construct the typology that led her to recognize five clusters (Coxon 1987b). They were copied as such. Two variables from Goodwillie (1992) were copied as such, but the remaining three were constructed as follows. Goodwillie's (1992) 32 turlough plant communities were grouped into three main types based on Wheeler (1980a, 1980b, 1980c) and O'Connell et al. (1984). The groups are (1) grass/forb-dominated communities (from $2 \mathrm{~A}$ to $5 \mathrm{~B}$ ), (2) sedge-dominated communities (from $5 \mathrm{D}$ to $8 \mathrm{C}$ ), and (3) aquatic communities (from 9A to 11B), leaving out the woodland communities and open water (Goodwillie 1992). For each turlough, the area covered by these three groups was calculated and converted to a proportion of the total turlough area. Again, some variables were not available for every site, so only 54 sites were included in the Coxon/ Goodwillie dataset.

All statistical analyses were conducted using the statistical package PC-Ord (McCune and Grace 2002). Both datasets contain a mix of quantitative, semi-quantitative, and binary variables. All variables, except the ones that stand for type in the Gort dataset or cluster in the Coxon/Goodwillie dataset, were included in multivariate analysis (Table 2). They were all standardized to the standard deviate (transformed to $\mathrm{z}$-scores). Quantitative variables were log-transformed prior to standardization, and proportions were arcsine square root transformed prior to standardization (variables in bold in Table 2). Both datasets were subjected to NonMetric Multidimensional Scaling (NMS) (Clarke 1993, McCune and Grace 2002) on the matrix of sites by variables and to Cluster Analysis (Ward's method). NMS was used because, unlike other multivariate techniques, it requires a minimum of assumptions about the data and can handle a variety of variables with a minimum of distortions (McCune and Grace 2002). It thus provided a new way of looking at 'old' data. Both the NMS and the cluster analysis were carried out using the Euclidean distance measure. NMS was carried out with random starting configurations. The preliminary runs (30) were done using a six- to one-dimensional solution, a Monte Carlo test with 30 runs for each dimensionality, and an instability criterion of 0.0001 (McCune and Grace 2002).

The ordinations obtained with NMS form a picture on which to overlay the types generated by the appropriate typologies (Coxon (1986) for the Coxon/Goodwillie dataset and Southern Water/ Jennings and O'Donovan (1997) for the Gort dataset). For each dataset, this overlay can then be compared with two overlays generated by the cluster analysis. The first overlay aims to reproduce the types of the appropriate typology by defining a cutoff level of the same number of groups (five clusters for Coxon and nine types for Southern Water/ Jennings and O'Donovan). The second overlay opposes the dry and wet extremes of an overall dry-wet gradient by defining a cut-off level of two groups.

The two datasets have nine turloughs in common, all situated in the Gort lowlands. These nine turloughs are labeled individually in the score plots and mentioned where appropriate. Using these nine common turloughs, a Mantel Test was run between both Euclidean distance matrices to check how well the typologies emerging from each dataset correlate with one another. The Mantel test gives a standardized Mantel statistic $r$ (ranging from -1 to +1 ), similar to a correlation coefficient, an observed $\mathrm{Z}$ (sum of cross products), and a probability p. A randomization test was then used to assess the chances that the observed $\mathrm{Z}$ could have been generated by chance alone. Hence, $p$ is the proportion of randomized runs with $Z$ more extreme than or equal to the observed $\mathrm{Z}$ (McCune and Grace 2002).

\section{RESULTS}

Table 3 summarizes the main characteristics of the NMS-output (further details in Appendix, especially for the binary variables that are not plotted on the figures). Both datasets led to a threedimensional solution with an acceptable final stress 
Table 2. List of variables, sources and units. In bold are variables that were transformed prior to standardization.

\begin{tabular}{|c|c|c|c|c|}
\hline & & Variable & Units & NMS \\
\hline Gort dataset & & & & \\
\hline & 1 & Conductivity & $\mu \mathrm{S} \mathrm{cm}$ & + \\
\hline & 2 & Alkalinity & Low 1 , medium 2 , high 3 & + \\
\hline & 3 & Water level fluctuation & $<3 \mathrm{~m}: 1$ and $>3 \mathrm{m:} 2$ & + \\
\hline & 4 & Response to rainfall & Slow 1 , medium 2 , fast 3 & + \\
\hline & 5 & Summer water & None or pools: 1 and pond/lake: 2 & + \\
\hline & 6 & Date of draining & Early 1 , medium 2 , late 3 & + \\
\hline & 7 & Marl & Absence 0 , presence 1 & + \\
\hline & 8 & Drift thickness & $<0.25 \mathrm{~m}: 0,0.025-0.75 \mathrm{~m}: 1,>0.75 \mathrm{~m}: 2$ & + \\
\hline & 9 & $\begin{array}{l}\text { Nutrient status } \\
\quad \text { Littorella uniflora } \mathrm{L} .\end{array}$ & Scale from 1 (nutrient poor) to 10 (nutrient rich) & + \\
\hline & 10 & $\begin{array}{l}\text { Asherson (indicator of exposed } \\
\text { mud) }\end{array}$ & Absence 0 , presence 1 & + \\
\hline & 11 & Reedbeds & Absent 0 , small 1 , extensive 2 & + \\
\hline & 12 & Type & A-I (see Table 1$)$ & \\
\hline Coxon/Goodwillie & $\operatorname{atas}$ & & & \\
\hline Coxon (1986) & 1 & Floor & $\begin{array}{l}\text { Flat } 1 \text {, flat with slopes } 2 \text {, gently undulating } 3 \text {, } \\
\text { undulating } 4 \text {, compound } 5\end{array}$ & + \\
\hline & & Slopes & $\begin{array}{l}\text { Gentle }(<5 \%) 1 \text {, gentle with scarps } 2 \text {, moderate } \\
\quad(5-15 \%) 3 \text {, steep }(>15 \%) 4 \text {, variable } 5\end{array}$ & + \\
\hline & 3 & Depth of flooding & $<1 \mathrm{~m}: 1,1-2 \mathrm{~m}: 2,2-3 \mathrm{~m}: 3,>3 \mathrm{~m}: 4$, variable: 5 & + \\
\hline & 4 & Irregularity index & $\begin{array}{l}\text { Perimeter of flooding/ circumference of circle of } \\
\text { turlough area }\end{array}$ & + \\
\hline & 5 & Elongation index & $\begin{array}{l}\text { Average of two elongation indexes: max. length/ } \\
\text { diameter of turlough area and max. } \\
\text { length/max. breadth }\end{array}$ & + \\
\hline & 6 & Marl only & Absence 0, presence 1 & + \\
\hline & 7 & Peat or peat-marl & Absence 0, presence 1 & + \\
\hline & & $\begin{array}{l}\text { Mineral deposits according to } \\
\text { impermeability }\end{array}$ & Absence 0 , sand/silt 1 , silt/clay 2 , diamicton 3 & + \\
\hline & & Extent of limestone outcrop & Little or none 1 , some 2 , much outcrop 3 & + \\
\hline & & Altitude & $\begin{array}{l}<25 \mathrm{~m}: 1,25-49 \mathrm{~m}: 2,50-74 \mathrm{~m}: 3 \\
75-99 \mathrm{~m}: 4,>100 \mathrm{~m}: 5\end{array}$ & + \\
\hline & & Cluster & $1-5$ (see Table 1$)$ & \\
\hline Goodwillie (1992) & 12 & $\begin{array}{l}\text { Turlough catchment area/turlough } \\
\text { area }\end{array}$ & Dimensionless & + \\
\hline & 13 & Alkalinity & Low 1 , medium 2 , high 3 , very high 4 & + \\
\hline & & $\%$ grass dominated communities & Proportion & + \\
\hline & & $\%$ sedge dominated communities & Proportion & + \\
\hline & 16 & $\%$ aquatic communities & Proportion & + \\
\hline
\end{tabular}

$(<20 \%)$ and low instability $(<0.0001)$. The proportions of variance explained by each of the three axes show that, for both datasets, one axis explains the bulk of the variation. Since the final stress is still $>10 \%$, the features displayed by secondary axes have to be interpreted with caution (McCune and Grace 2002).

\section{Gort Dataset}

The NMS ordination (Figure 2) extracted a high proportion $(86.8 \%)$ of the total variation in the dataset, with $50.2 \%$ of the variation loaded on Axis 2 and 22.5\% loaded on Axis 1. The main axis (Axis 2) shows two sets of strongly correlated variables (Figure 2). It shows a positive correlation between response to rainfall and nutrient status on the one hand and a positive correlation between alkalinity, conductivity, and the presence of marl (binary variable, not plotted in Figure 2 but see Appendix) on the other hand. These sets are negatively correlated with one another (opposite sides of Axis 2). Thus, wetlands that respond quickly to rainfall generally have a high nutrient status but low 
Table 3. Summary of results of NMS ordinations for both datasets.

\begin{tabular}{lcc}
\hline \multicolumn{1}{c}{ DATASETS } & Gort & Coxon/Goodwillie \\
\hline Monte Carlo Test p (for each dimensionality 1 to 6) & 0.0400 & 0.0323 \\
Selected final dimensionality (based on scree plot and $<5 \%$ reduction in stress by & 3 & 3 \\
$\quad$ adding one dimension) & 77 & 0.00008 \\
Number of iterations for final solution & 12.6 & 0.00009 \\
Final instability (standard deviation in stress over last 20 iterations) & 16.0 \\
Final stress (\%) & 0,225 & $\mathbf{0 , 5 0 2}$ \\
Determination coefficient between distance in ordination space and distance in original space (main axis in bold) & 0,185 \\
Axis 1 & 0,141 & 0,205 \\
Axis 2 & $\mathbf{0 . 8 6 8}$ & $\mathbf{0 , 4 0 3}$ \\
Axis 3 & $\mathbf{0 . 7 9 3}$ \\
\hline
\end{tabular}

alkalinity and conductivity; the converse was true for wetlands that respond slowly to rainfall. Examples of the former extreme include Blackrock, Garryland, and Caherglassaun, and of the latter extreme Termon South, Caranavoodaun, and Ballinderreen (Figure 2). Axis 1 (the second most important axis) is correlated positively with the presence and extent of reedbeds, date of drainage, and the presence of summer water. Axis 1 thus separates wetlands that dry out early and cannot support reedbeds from wetlands that are more permanent and/or very late draining in summer. An example of the former extreme is Kiltiernan and of the latter extreme Termon South (Figure 2).

The Southern Water/Jennings and O'Donovan (1997) typology (A-I) (Table 1) is overlaid on the NMS ordination in Figure 2. 'Riverine turloughs' (types A and B) and 'dry sites without summer water' (types G, H, and I) (Table 1) are well defined. 'Riverine turloughs' score negatively on Axis 2 (fast response to rainfall, high nutrient status, low alkalinity and conductivity, no marl) (See also Appendix). 'Dry sites without summer water' all have negative scores on Axis 1 (early draining, no summer water, and no reedbeds but slower response to rainfall, more oligotrophic, more alkaline water and marl than riverine turloughs). However, the "wet sites with summer water' (types E and F) merge with the wetlands that are not considered turloughs (types C and D) because of the permanency of water (shown by the presence of reedbeds) (Figure 2). Likewise, the wetland types $\mathrm{C}$ to $\mathrm{F}$ are more closely clustered in that corner (positive sides of both Axis 1 and 2), meaning that they are much less distinct from each other than types A and B. Therefore, Figure 2 separates Southern Water/Jennings and O'Donovan's (1997) distinct 'riverine turloughs' and 'dry sites without summer water' from less distinct 'wet sites with summer water.'

Cluster analysis confirms that working with two main groups of turloughs is more meaningful than with nine groups. An overlay of the cluster analysis with the cut-off point at nine groups only partially reproduces the A-I typology (not shown). An overlay of the cluster analysis with the cut-off point at two groups on the same ordination (Figure 2) splits most of the 'riverine turloughs' (Types A and B) and some of the 'dry sites without summer water on drift (Type $\mathrm{G}$ ) from the other types (mainly $\mathrm{C}$ to F). Therefore the legend of Figure 2 names the two cluster groups 'dry' and 'wet.'

In summary, the NMS of the Gort dataset produced a stable and satisfying solution with more than half of the explained variation loaded on one main axis. Of the 11 variables used for ordinating the Gort dataset, seven have high loadings on the main axis (Appendix). The score plot (Figure 2) shows a fairly even spread of turloughs along the main axis, and the predefined types are not well separated as distinct clusters.

\section{Coxon/Goodwillie Dataset}

The NMS ordination extracted a high proportion $(79.3 \%)$ of the variation in the dataset. One main axis (Axis 3) carries $40.3 \%$ of the total variation, and two secondary axes (Axis 1 and 2) carry $18.5 \%$ and $20.5 \%$ of the variation, respectively (Figures 3 and 4). Turloughs located on the bottom left quadrant of Figure 3 and bottom right quadrant of Figure 4 are dominated by grass communities, tend to have a more regular form (i.e., a shoreline close to a circle in shape), have undulating floors, and steeper or variable slopes. They also tend to be covered with 


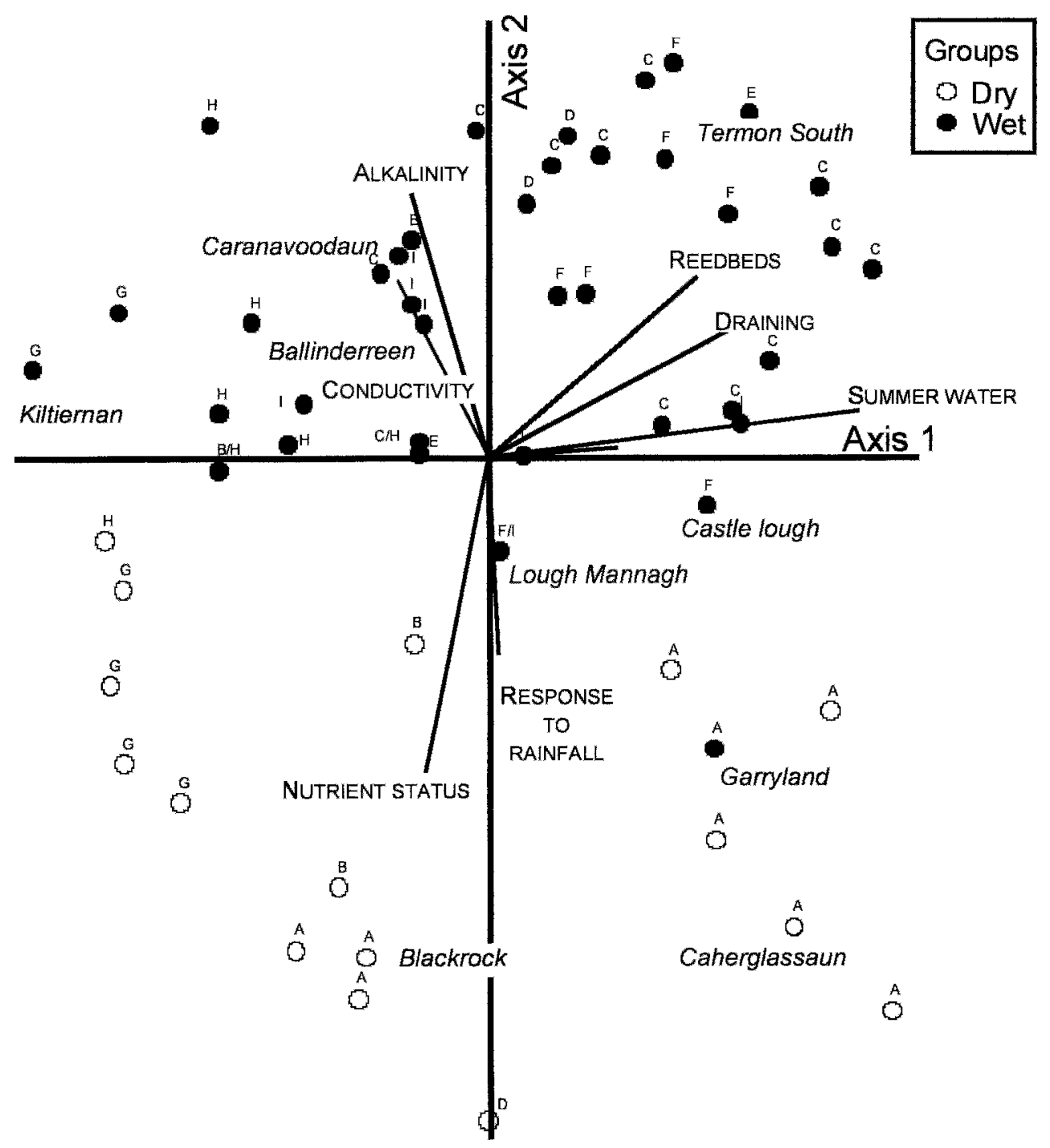

Figure 2. Gort Dataset: NMS Ordination of 54 wetlands in variable space, with $50.2 \%$ of the variation loaded on Axis 2 , $22.5 \%$ loaded on Axis 1 and $14.1 \%$ on Axis 3. Southern Water/Jennings and O'Donovan (1997) typology (A-I, see Table 1) and the two main groups of the cluster analysis are overlaid. The nine turloughs common to both datasets are labelled. All variables where $\mathrm{r}^{2}>0.2$ are shown as vectors, except binary variables.

mineral deposits and to experience deeper or more variable flooding (Figures 3 and 4; see also Table 2). They receive less alkaline water and tend not to form peat or deposit marl (Appendix). Generally, their scores on Axis 1, 2, and 3 are positive, negative, and negative, respectively. Blackrock and Kiltiernan are extreme examples of this type (Figures 3 and 4). They include Coxon's Cluster 5 ('diamicton turloughs,' Table 1). At the other end of Axis 3, there is a group of turloughs with more irregular shapes, flatter floors, gentler slopes, with little or no mineral deposits, and shallower flooding (Figures 3 and 4, Table 2). These tend to receive more alkaline water, form peat, and deposit marl (Appendix). This type can be dominated either by aquatic or sedge communities. Generally, their scores on Axis 1, 2, and 3 are negative, positive, and positive, respectively (Figures 3 and 4). Examples are Termon South, Ballinderreen, Castle Lough, and Caranavoodaun, which correspond with Coxon's Cluster 3 ('fen-like turloughs,' Table 1). Aquatic communities are strongly and positively correlated with marl deposition and peat formation and negatively correlated with the presence of mineral deposits (Appendix).

The overlay of the five clusters of Coxon's (1987b) typology in Figures 3 and 4 shows that the NMS does not separate them well. The overlay of a cluster 
analysis with a cut-off point at five groups (not shown) does not reproduce the same clusters. Cluster 5 does stand out, but the individual turloughs are well spaced, as was the case with the Gort dataset. The cluster analysis with a cut-off point at two groups is overlaid on the NMS ordination in Figures 3 and 4 as well. On the one hand, fen-like turloughs (Coxon's Cluster 3, Table 1) are mainly grouped together in the same quadrant (positive side of Axis 2 and 3). These include Castle Lough and Caranavoodaun. Grassy turloughs (Coxon's Cluster 4, Table 1) and diamicton turloughs (Coxon's Cluster 5, Table 1) belong to the other main group (opposite quadrant), with the exception of Ballinderreen. As in the Gort dataset, the main groups recognized by cluster analysis separate along the main axis, with 'fen-like turloughs' at one extreme and 'diamicton turloughs' at the other. The legends of Figures 3 and 4 thus label the former group 'wet' and the latter group 'dry.' The remaining types (Clusters 1 and 2, Coxon's 'typical turloughs,' Table 1) are scattered between both groups. They include Termon South (Cluster 1 but wet group) and Garryland (Cluster 2 but dry group). Overall, the most extreme clusters of Coxon (1987b) can easily be positioned at either side of a dry-wet gradient, but the intermediate ones are split between the two main groups.

In summary, the NMS of the Coxon/Goodwillie dataset also produced a stable solution with more than half of the explained variation loaded on one main axis. Of the 15 variables used for ordinating the Coxon/Goodwillie dataset, eight have high loadings on the main axis (Appendix). The score plots (Figures 3 and 4) show a fairly even spread of turloughs along the main axis, and Coxon's clusters merge into one another. The results are thus very similar to those of the Gort dataset.

\section{Correspondence Between Datasets}

The distance matrices of the Gort and the Coxon/ Goodwillie datasets are positively correlated $(\mathrm{r}=$ $0.588, p=0.002$ and observed $Z>$ average $Z$ from randomized runs). This significant and positive correlation indicates that we can combine variables from the two datasets for the nine turloughs common to both and again apply cluster analysis (Figure 5). The dendrogram of Figure 5 separates two major groups that correspond to the dry-wet gradient identified in Figures 2 to 4 . It separates wet (Ballinderreen, Caranavoodaun, Lough Mannagh, Termon South, and Castle Lough) from dry turlough extremes (Blackrock, Kiltiernan, Caherglassaun, and Garryland). Moreover, it confirms how the wet turloughs are more similar to one another than the dry ones, as the wet group clusters together at a much lower level of information than the dry group. The dry turloughs Kiltiernan and Blackrock are particularly dissimilar from one another, a pattern already seen in the score plots for the separate datasets (Figures 2 to 4). According to the Euclidean distance matrix (not shown), Blackrock and Termon South are the most dissimilar of the nine turloughs.

Our results can be summarized in two points: 1 . One main gradient. Both ordinations separate turloughs in a similar fashion (Figures 2, 3, and 4), although the datasets have only nine turloughs and two variables (alkalinity and the presence or absence of marl or peat/marl, see Table 2) in common. In both datasets, NMS gives these variables high loadings on the main axis (Appendix) and correlates them with several other variables. For each dataset, cluster analysis with a cut-off point at two groups separates two main groups with similar characteristics. The ecological distances between the nine turloughs common to both datasets are positively correlated. The same cluster analysis applied to the combined dataset assigns them to the same two main groups as in the individual datasets (compare Figures 2-5). Further splitting of these groups does not seem ecologically meaningful with the data we have. 2. Types not reproduced. The variables weakly support the turlough typologies that rely on them. Spread is fairly even along the main axis and no distinct clusters appear.

\section{DISCUSSION}

\section{Dry-to-Wet Continuum}

Looking back at the origin of the data, the analysis of which yielded one main gradient in turlough variation but no distinct types, two issues stand out. 1. Unclear data gathering. The variables used were those produced by various authors, published and unpublished; it is not always clear how these have been collected and collated. The only fully quantitative measurement is conductivity, yet even for this, there is no information on how, when, and where this was measured. The majority of variables are semi-quantitative or binary, which might reflect the difficulty and even the flaw of assigning one value to one turlough as there may be variation across one site in that variable. 2. Coherent ordination output. Despite reservations about the nature and quality of the data, the main results of this study strongly suggest that the main gradient driving turlough variation is a dry-wet gradient. 


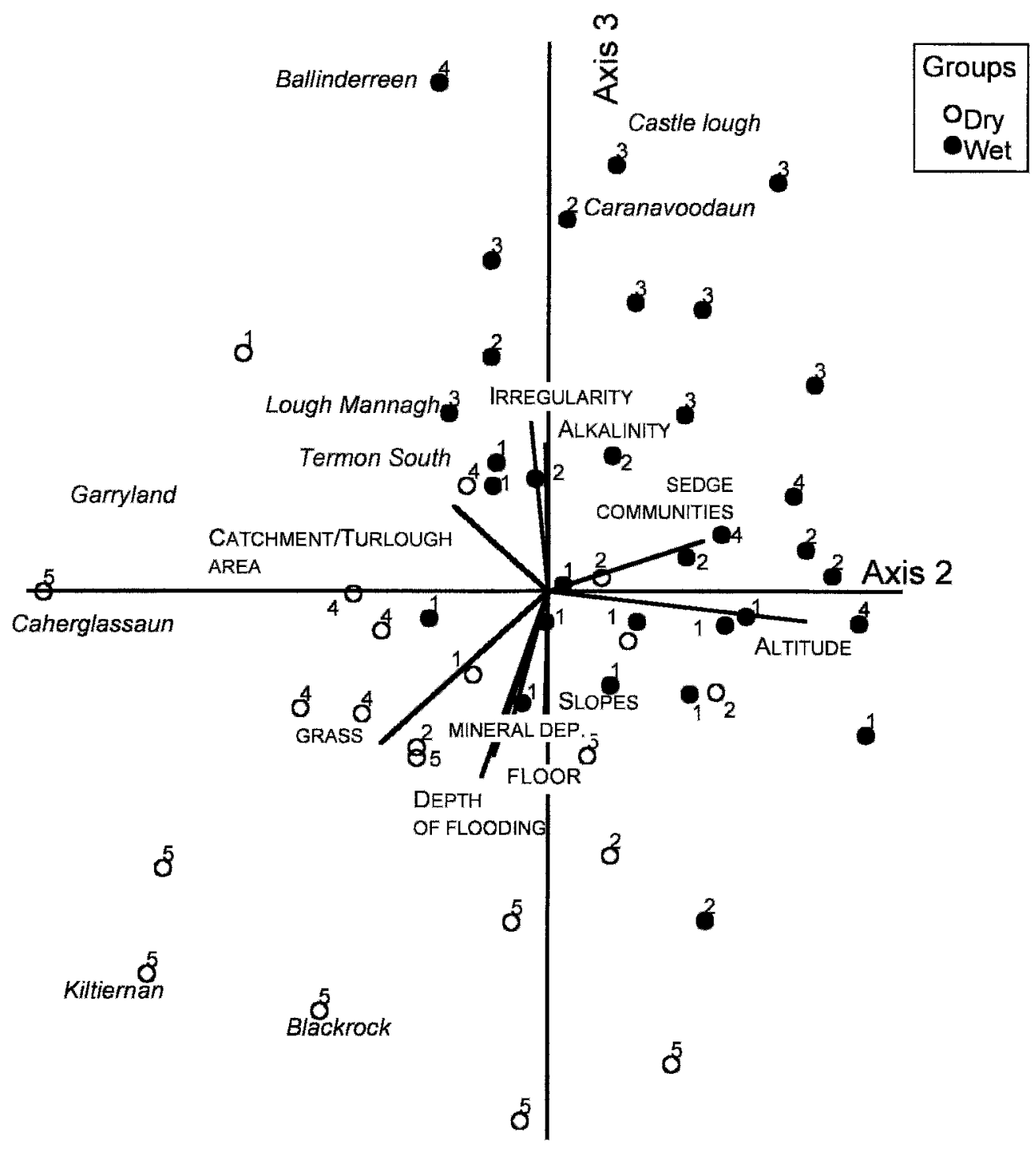

Figure 3. Coxon/Goodwillie Dataset: NMS Ordination of 54 turloughs in variable space with environmental variables overlaid, $40 \%$ of the variation loaded on Axis 3 and 21\% loaded on Axis 2. Coxon's (1987) typology (Clusters 1-5) and the two main groups of the cluster analysis are overlaid. The nine turloughs common to both datasets are labelled. All variables where $\mathrm{r}^{2}>0.2$ are shown as vectors, except binary variables.

Hence, it is more appropriate to think of this variation as an ecological continuum involving multiple related factors rather than a collection of distinct types. The variables both datasets have in common are at the same time the main determinants of the distinction between wet and dry-wet turloughs being characterized by high alkalinity and the likely presence of marl and/or peat/marl and vice versa. The correlation of these variables with the other important variables of both datasets show that this dry-wet gradient relates to other gradients, hence the term continuum. Based on the variables used in this study, no other major gradient is at work independently from the dry-wet gradient. That is, the three major ecological gradients $(\mathrm{pH}$, availability of nitrogen and phosphorus, and water level) identified by Wheeler and Proctor (2000) covary.

Although hydroperiod is not a variable, several significant variables from the two datasets are proxies for it. When combined using the variables common to both datasets, they yield a fairly complete description of the turlough hydroperiod. From the Gort dataset, it can be deduced that wet turloughs, whose filling and emptying respond slowly to rainfall patterns, drain late in the season 


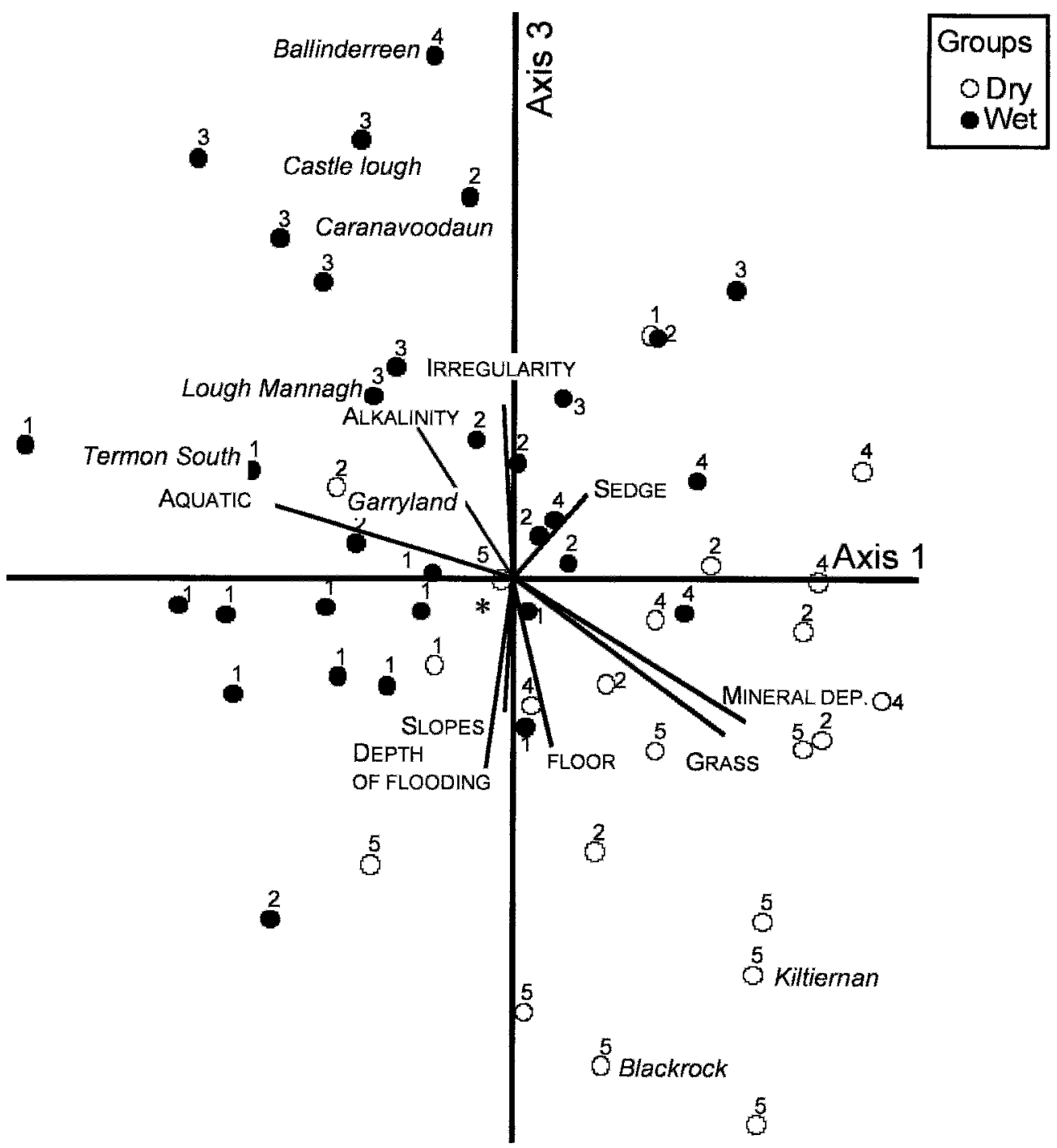

Figure 4. Coxon/Goodwillie Dataset: NMS ordination of 54 turloughs in variable space with environmental variables overlaid, with $40 \%$ of the variation loaded on Axis 3 and 19\% loaded on Axis 1. Coxon's (1987) typology (Clusters 1-5) and the two main groups of the cluster analysis are overlaid. The nine turloughs common to both datasets are labelled. All variables where $\mathrm{r}^{2}>0.2$ are shown as vectors, except binary variables. ${ }^{*}$ Caherglassaun turlough.

INFORMATION REMAINING (\%)

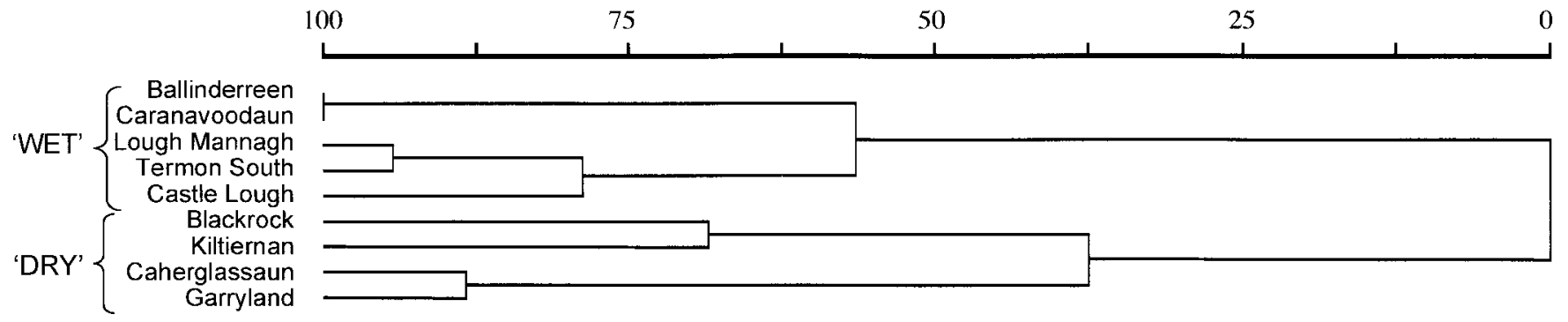

Figure 5. Dendrogram obtained by cluster analysis (Euclidean distances, Ward's method) using the variables related to these nine turloughs from both the Gort Dataset and the Coxon/Goodwillie Dataset. 
and are likely to pool water throughout the summer. They thus have a long hydroperiod, and this long hydroperiod is conducive to peat formation and marl deposition. In the Coxon/Goodwillie dataset, a long hydroperiod, peat formation, and marl deposition go along with shallow flooding of turloughs. Both datasets suggest that long hydroperiods are associated with more alkaline water. Table 4 describes the extremes of a turlough continuum as they emerge from this analysis and adds more elements that will arise from our description of turloughs as features of the hydrogeology of Irish lowland karst.

\section{Links with Karst Hydrology}

The most fundamental difference between the wet and dry turlough extreme is the origin of the water feeding it, which is closely associated with the degree of karstification of the limestone. Recent karstification produces young karst, called epikarst or subcutaneous karst, characteristic of most wet turloughs. The widening of fissures and cracks along joints and bedding planes of the limestone is at first limited to the upper meters of the rock. For example, Drew (1990) mentioned a depth of 2 to $2.5 \mathrm{~m}$ of karstification in the Irish Burren. As karstification proceeds, the epikarst matures toward conduit or deep karst, where the solutionally widened fissures along vertical joints connect with deep subterranean conduits, characteristic of most dry turloughs.

There are important hydrologic differences between epikarst and deep karst (Sweeting 1972, 1973, Williams 1983, Jennings 1985, Ford and Williams 1989). In general, deep karst is characterized by rapid drainage by conduit flow, whereas epikarst sustains slower diffuse flow with a strong lateral component. Hence, residence time of deep karst water is much shorter than that of epikarst water. Residence time or age is one of the most important defining characteristics of karst water. The degree of saturation of a water with respect to calcium carbonate is a direct measure of its age within a karst drainage system (Sweeting 1973). Therefore, water in turloughs located in deep karst with rapid drainage and shorter hydroperiods will have lower $\mathrm{CaCO}_{3}$ concentrations than water in turloughs located in epikarst with slow drainage and long hydroperiods. This explains why alkalinity is such an important variable in the dry-wet turlough gradient (Figures 2 to 4). Epikarst turloughs have well-defined hydrologic catchments based on short ground-water flow paths from the immediate topographical watershed. The water of wet tur- loughs is nutrient-poor not only because of its high alkalinity but also because their catchments are generally much smaller. By contrast, deep karst ground water can feed from or into different watersheds and even originate from rivers on nonlimestone areas, which makes watersheds difficult to define.

It is important to recognize that the classical concept of a ground-water table in hydrology does not hold in mature karst and that, in karst hydrology, the classical distinction between ground water and surface water is blurred (Coxon and Drew 1998, 2000). However, as long as the role of the subcutaneous zone is still great (in immature karst), the contrast between karst and normal fluvial hydrology is reduced (Jennings 1985). Interestingly, this intermediate situation is exactly what Coxon and Drew (1986) and Drew (1992) have found for Irish core turlough areas such as the catchments of the rivers Robe (near the town of Ballinrobe), Clare (between Ballinrobe and Galway), and Dunkellin (just north of the Gort area) (Figure 1). Since epikarst is a feature of all limestone currently exposed to karstification, most if not all turloughs are fed by epikarst water to some degree and owe their distinct seasonal fluctuations to the seasonality of the water table associated with epikarst.

\section{The Gort Lowlands}

Deep karst and epikarst can be superimposed within the same limestone setting. The Gort lowlands, north east of the Burren (Figure 1), are a good example of this superposition and have been extensively studied (Southern Water/Jennings and O'Donovan 1997). They provide a case study to describe further the dissimilarity of dry turlough extremes associated with deep karst and wet turlough extremes associated with epikarst. Both Ford and Williams (1989) and Simms (2003a, b) described the Gort lowlands as an extensive corrosion plain of late Tertiary origin. It is said to cut across various thick Carboniferous limestone strata upfolded to the east, where a north-south range of low hills of Devonian sandstone (the Slieve Aughty mountains, Figure 1) has been unroofed from beneath the limestone. Since unroofing this sandstone, the rivers that drain westward toward the Atlantic have been bringing allogenic and chemically aggressive surface water onto the limestone and have eroded exceptional cave passages in the most karstifiable strata flooring the corrosion plain. The glaciations interrupted this Tertiary karstification, destroyed much of the karst landscape and infilled much of the subterranean features (Drew and Jones 
Table 4. The dry-wet continuum concept for turlough variability. The general characteristics for the extremes of the drywet continuum are listed. Turloughs occurring in the middle of this continuum may have characteristics of both extremes.

\begin{tabular}{|c|c|}
\hline Dry extreme & Wet extreme \\
\hline \multicolumn{2}{|c|}{ HYDROLOGY AND GEOMORPHOLOGY } \\
\hline Deep karst & Epikarst \\
\hline High water fluctuations & Low water fluctuations \\
\hline Relatively low alkalinity & High alkalinity \\
\hline Short hydroperiod & Long hydroperiod \\
\hline \multicolumn{2}{|c|}{ SUBSTRATES } \\
\hline Mainly mineral deposits & Frequent peat \& marl \\
\hline Deep and steep slopes & Shallow and gentle slopes \\
\hline No flat floors & Flat floors \\
\hline Dry soils in summer & Moist soils throughout summer \\
\hline \multicolumn{2}{|c|}{ ECOLOGICAL COMMUNITIES } \\
\hline Grass dominated communities & Sedge and aquatic communities \\
\hline Wetland ruderal plant species & Nutrient-stress tolerant plant species \\
\hline Opportunistic aquatic and terrestrial invertebrates & Wetland specialist invertebrates \\
\hline
\end{tabular}

2000). What is left of this preglacial karst are subterranean fragments at depths of $5-15 \mathrm{~m}$ below present sea level (Drew and Daly 1993). Since the last glaciation, however, karstification has started anew because the glacial deposits were shallow. The old allogenic drainage system could partially reactivate the old passages, and superimposed on this, a new epikarst drainage system could develop.

In the east of the Gort lowlands, the allogenic rivers reappear several times to flow on the surface before sinking once more. They are at the origin of a small and distinct set of Goodwillie and Reynolds' (2003) 'riverine turloughs' that represent the dry extreme of the gradient. These turloughs can be viewed as pressure release valves (Coxon, pers. comm.) or as surge tanks (Johnston and Peach 1998) on major karst conduits that carry water from vast and barely definable areas. As the Gort dataset shows, however (Figure 2), riverine turloughs are greatly outnumbered by wetter turloughs and other wetlands. Either these exist away from the major flow lines of deep karst, in smaller and better definable catchments purely underlain by epikarst, or they result from the partial blocking of deep karst conduits by in-washed sediments of glacial origin (Drew and Daly 1993, Drew and Jones 2000) or from poorly developed pathways in the limestone subcrop (Johnston and Peach 1998). The maps of the Gort flooding study show (Southern Water/ Jennings and O'Donovan 1997) that wet and dry extremes can actually occur within small distances of one another and even merge during extreme floods. Typologies do not allow room for this kind of nuance nor for within-site variation.
Figure 6 is a diagrammatic representation of the differences between a dry turlough extreme (Blackrock) and a wet turlough extreme (Termon South), the most dissimilar pair of the nine turloughs common to both datasets. Blackrock is a typical 'riverine turlough' just downstream from the geological contact with the Old Red Sandstone and fed by a major allogenic river that drains part of the Slieve Aughty hills. It feeds into a complex of hydrologically connected turloughs downstream (Drew 2003) that all function as dry turloughs. Throughout the summer, its floor is dry, but deluge conditions can flood Blackrock overnight to a depth of several meters (Southern Water/Jennings and O'Donovan 1997). Termon South, on the other hand, is fed through epikarst and is border line between a fen and a turlough. The hydrograph shows a very gentle seasonal change in water level. Throughout the summer, the turlough is fed by a constant trickle of epikarst water because its floor is below the summer water table. The water ponds because of impeded drainage of the turlough floor (Southern Water/Jennings and O'Donovan 1997).

Whether drainage through the turlough floor is impeded or not depends on the position of the swallow holes combined with the nature of the turlough floor deposits and the underlying rock. The majority of turloughs have swallow holes at the edge of the turlough floor (Coxon 1986, Goodwillie and Reynolds 2003). Once the water level has dropped below the level of the swallow holes, further drainage depends on the nature of the underlying rock and floor deposits. The 
underlying rock may be muddy limestone, one of the older strata of the Gort corrosion plain and not susceptible to karstification (Drew and Daly 1993, Simms 2003a, b). This is the case in Termon South (Figure 6), so any remaining water will pond. Marl deposition (because of the highly alkaline epikarst water) and peat formation are likely to occur, causing the turlough to pond even more. By contrast, Blackrock features a central swallow hole in the lowest part, which allows for bathtub-like emptying, and a highly karstified rock under the turlough floor, which results in fast draining (Figure 6). Ponding, marl deposition, and peat formation are unlikely to occur.

Origin of Turloughs: Further Arguments for a Continuum Concept

Some differences in geomorphology between dry and wet turlough extremes can be interpreted in terms of their speculated origin and evolution. In particular, the role of the Quaternary glaciations in their formation and/or development is a matter for considerable debate. Turloughs were originally thought of as glacial depressions adapted to karst drainage (Williams 1970, Ford and Williams 1989). However, Drew (1976) later stated that 'turloughs are invariably bedrock hollows and not simply declivities in the glacial drift.' Coxon (1986) considered both options plausible but lacked data to confirm either explanation. Later, Coxon and Coxon (1997) suggested that turloughs might be polygenetic features: some may be glacial hollows while others may have a more complex history involving a solutional process resulting in bedrock hollows, later modified by glacial processes.

If a turlough is found to be a solutional feature, its origin must date back to preglacial times because a well-developed network of closed depressions has not had time to develop in karstic areas of Ireland since the last glaciation. Indeed, interglacial solutional processes could do little more than reactivate and modify existing karst landforms. Coxon and Coxon (1997) even suggested that lines of high permeability in the aquifer associated with turloughs may represent the re-use of remnants of a drainage network created by extensive karstification during the Tertiary. Today, drainage networks are partially clogged by glacial drift and therefore inefficient at coping with high flows, resulting in the expulsion of water under pressure and surface ponding in turloughs.

Dry turlough extremes are more likely to have been closed depressions originally, resulting from preglacial karstification processes, which were sub-
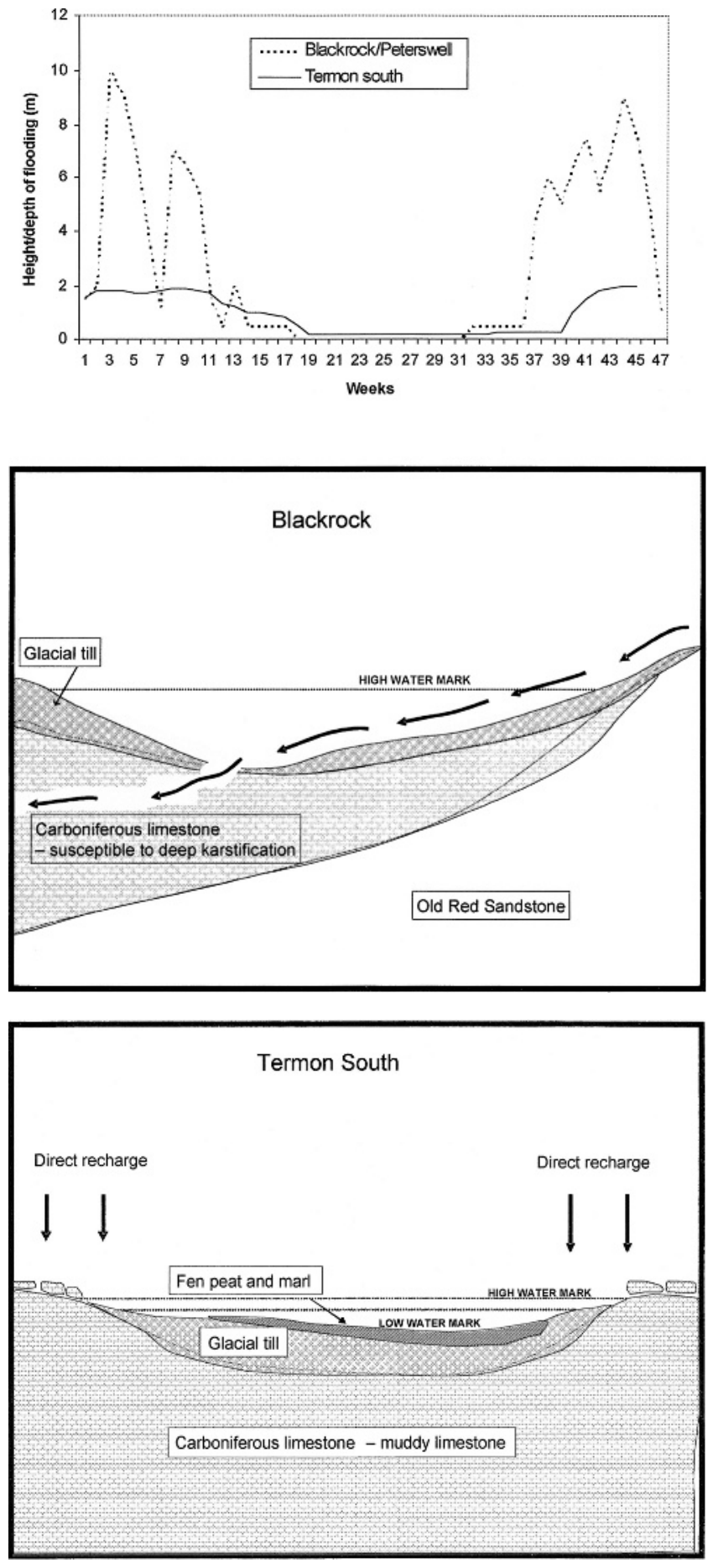

Figure 6. Blackrock and Termon turloughs - comparison of water levels in 1996 and schematic cross-sections. Hydrographs are approximate copies from Southern Water/Jennings and O'Donovan (1997) and cross-sections are drawn collating various descriptive data from Southern Water/Jennings and O’Donovan (1997). 
sequently modified by glacial erosion and deposition (Drew and Jones 2000)-hence their more regular shape, their steeper or variable slopes with rock outcrops and an undulating floor, presumably because of collapses of conduits underneath. Presumably also, if chemically aggressive water has resumed its corrosive action in the turlough since the last glaciation, it can be speculated that turloughs receiving this water are continuing to grow. Wet turlough extremes, on the other hand, are more likely to have a more recent glacial or postglacial origin, as Williams (1970) saw it. The alkalinity of epikarst water combined with impeded drainage leads to depositional rather than solution processes, so that an ecological succession via fen to groundwater-independent terrestrial ecosystems can be speculated, hence their more irregular shape (they flood pre-existing contour lines) and their gentler slopes. Wet and dry extremes thus seem to evolve in quite opposite directions. Therefore, they should be treated as ecologically distinct.

\section{Consequences for Turlough Ecology}

Understanding the processes that bring about the dry-wet continuum in turloughs gives insight into the variation of the main ecological factors along this continuum, which are level of disturbance and nutrient status. The dry turlough extreme provides a less predictable but more nutrient-rich habitat for wetland organisms than the wet extreme. This difference in level of disturbance and correlated nutrient status applies to both the aquatic and terrestrial phases of turloughs. Several factors are at play here. First, a dry turlough extreme is likely to be fed by waters that have travelled greater distances and picked up nutrients and sediments (Coxon and Drew 1998, 2000). Second, as a general rule, nutrient status increases in wetlands with the frequency of drying and disturbance (Haslam 2003), and dry turloughs experience more drying and disturbance than wet turloughs. Third, a dry turlough extreme is likely to be fed by less alkaline water, and it is known that wetlands at both extremes of the alkalinity gradient (ombrotrophic bogs and highly calcareous fens) have a lower nutrient status than wetlands of intermediate alkalinity (Wheeler and Proctor 2000). Fourth, in dry turloughs, the presence of layers of nutrientpoor marl and peat is less likely, so underlying mineral soil is left exposed. The dry turlough extreme is therefore likely to be more nutrient-rich and thus less sensitive to nutrient pollution. Altering land use to mitigate water pollution would be difficult because the catchments of dry turloughs are large and hard to define. The floor of a dry turlough extreme is characterized by more vigorous disturbance-adapted grass communities (Figures 3 and 4) that can support greater grazing pressures. By contrast, a wet turlough extreme can have fenlike features, with soils retaining high moisture levels throughout the year. They are fed by direct discharge from the immediate surrounding area. Wet turloughs are nutrient-poor and more sensitive to water pollution. However, because the catchment is comparatively small and easier to define, efforts to reduce water pollution are more effective. The vegetation is dominated by sedge and aquatic communities (Figures 3 and 4) that are tolerant of nutrient stress but cannot support high grazing pressures. Turloughs falling in the center of the dry-wet continuum can be managed sensitively by considering the input of water from both the immediate watershed and beyond that give rise to 'wet' and 'dry' influences, respectively.

Several publications on turlough ecology can be interpreted by contrasting 'disturbed and nutrientrich' versus 'less disturbed and nutrient-poor' communities. Ivimey-Cook and Proctor (1966) and O'Connell et al. (1984) described the vegetation of turloughs as part of larger vegetation studies of Irish wetlands. Ivimey-Cook and Proctor (1966) classified most of their relevés from turloughs into two main phytosociological classes, the ScheuzerioCaricetea fuscae, and the Plantaginetea majoris, describing small-sedge communities and communities of disturbed habitats, respectively. A third class describing lakeshore communities, the Littorelletea, is found on the margins of more permanent water bodies that have turlough-like properties. O'Connell et al. (1984) collated many of Ivimey-Cook and Proctor's (1966) relevés with those collected by MacGowran (1985) and others. The classification of the turlough relevés is roughly the same, apart from some differences in nomenclature. The vegetation classification may be broadly described as demonstrating a difference between oligotrophic, small-sedge-dominated swards and more vigorous high nutrient and/or disturbed vegetation. These differences may be ascribed, in part, to inundation frequency and substrate saturation (Ivimey-Cook and Proctor 1966, O'Connell et al. 1984). The interplay of these factors is illustrated by Ní Bhriain et al. (2002) in their description of the differences in vegetation composition between Caherglassaun (dry extreme with a ruderal dominated sward) and Caranavoodaun (wet extreme with fen-like sward).

This broad distinction between wet and dry types can also be seen in the invertebrate communities, 
both during the aquatic and the terrestrial phase. Generally, robust opportunistic species tend to dominate the communities of the dry extreme, whereas rare specialist species are limited to the wetter end of the gradient. Foster et al. (1992) considered that turloughs are occupied by a range of water beetle community types due to variations in the seasonal availability of water. Turloughs that do not drain down completely and stay wet throughout the summer appear to contain greater aquatic invertebrate abundance and to demonstrate greater community complexity (Duigan 1988). Reynolds (1997) found a more diverse aquatic fauna in hydrologically isolated, epikarst turloughs (longer hydroperiod) as opposed to deep karst (shorter hydroperiod) turloughs. The main factors affecting Lepidoptera on turloughs appear to be the surrounding habitat types. However, turloughs remaining damp in summer have a relatively richer fauna (Bond 1997). This author has observed that dragonflies and damselflies occur with more species and in greater numbers in turloughs with damp areas throughout the summer. Lestes dryas Kirby, the turlough spreadwing damselfly, in particular, appears to be restricted to wetter turloughs. The most critical factor for the survival of populations of this rare damselfly is the hydroperiod (Nelson and Thompson 2004). Summer soil moisture levels are among the most important environmental factors affecting epigeal invertebrates in wetlands, in general (Lott 2003, Sadler et al. 2004), and this pattern is also found in turloughs during their terrestrial phase (Good and Butler 2001, Ní Bhriain et al. 2002).

\section{Extending a Continuum Concept Beyond Turloughs}

When comparing turloughs with similar wetlands worldwide, we should look for seasonal groundwater-fed wetlands. It is useful to compare our turlough continuum concept with the wetland continuum concept of Euliss et al. (2004), derived from studies on temporary wetlands in the prairie pothole region (PPR) of North America. Both concepts emphasize the hydrologic relation of a seasonal wetland to ground water that cannot be inferred from topographical position alone. Euliss et al. (2004) saw a first major axis of variation in this and distinguished recharge, flow-through, and discharge wetlands depending on whether there is mainly gain or loss of water to ground water. In the turlough continuum, dry and wet extremes can be viewed as recharge and discharge wetlands, respectively, and the correlations with flow-path length, hydroperiod, nutrient status, and alkalinity of the water justify the term continuum. In contrast with western Ireland, however, the PPR has a semiarid climate with high potential evapotranspiration and huge inter-annual climatic variability, which led Euliss et al. (2004) to add a second axis of variation, ranging from deluge to drought. In that respect, prairie potholes are more subject to temporal shifts of their biological communities than turloughs. By simultaneously considering both axes of Euliss et al. (2004), it is possible to predict that biological communities of recharge, flow-through, and discharge prairie potholes will react differently to the same climatic extreme. Unlike with turloughs, evapotranspiration is a very significant factor in the water balance of prairie potholes. Whereas in the turlough continuum, ground-water flow-path length correlates with $\mathrm{CaCO}_{3}$ concentration; in the PPR continuum, it correlates with salt concentration, which becomes a major limiting factor to life in discharge prairie potholes (basically closed depressions).

While Euliss et al. (2004) based their wetland continuum concept on the literature on the PPR, they believe 'the concept has application to wetlands in many other geographical locations.' By contrast, the turlough continuum concept is an interpretation of the output of statistical data analysis, which did not show any obvious discontinuities yet correlation of the main ecological gradients. While we think the continuum concept is justified for the data we have now, the picture might change as new data become available. Most often, categories in ecological variation are made while implicitly recognizing their arbitrary nature. New data, or new analyis of old data, might actually back up these categories or reject them. For example, Wheeler and Proctor (2000) demonstrated a bimodal distribution of water $\mathrm{pH}$ of North-West European mires, which justified two main categories of mires (rich fens versus poor fens and bogs) but stated that there was no evidence for similar discontinuities in the fertility or water table gradients. To extend this idea further, while Wheeler and Proctor (2000) stated that the main ecological gradients within North-West European mires are independent, in general; this paper shows that they are correlated within one very particular category of wetland (turloughs). In summary, a wetland continuum versus typology concept can be backed up by the data or it cannot, depending on the data, the wetland type covered (in itself subject to debate as to where to draw the line), and the discontinuities and correlations revealed by data analysis. 


\section{CONCLUSIONS}

Turloughs were given priority status in Natura 2000 mainly because of their hydrogeological uniqueness resulting from karstification (one of the most complex and dynamic hydrogeological systems to model or typify) and the understudied effects of the Quaternary glaciations on Irish karst. Turloughs are renowned for being highly dynamic and unpredictable. However, understanding the extreme variability of turloughs is key to managing and conserving these Irish priority habitats. The reanalysis of the best available data on turlough variation, however limited, demonstrates that turloughs rarely fit existing typologies and suggests that a dry-wet continuum is a more ecologically meaningful perspective for understanding these systems and linking them to karst hydrogeology. Considering turloughs as highly heterogeneous karst features also aids in the recognition that very few turloughs fit the description of wet or dry. Most occupy a middle ground that cannot be adequately described by variables gathered on a perturlough basis. Forcing a typology on those turloughs for pragmatic reasons may cause more harm than good. Furthermore, karst-induced variation within turloughs (not studied to date) implies that typing turloughs for the sake of conservation becomes even more debatable. All efficient conservation management depends on fine-tuning general guidelines in recognition of local variation. In the case of turloughs, conservation managers are more likely to understand a flexible dry-wet continuum concept than a rigid turlough typology.

Another argument against typing turloughs consists of data limitations. Defining sound variables to describle turlough variation and gathering reliable and repeatable data for these variables is difficult. The difficulties involved partially explain why there is a general lack of baseline data on which to base turlough conservation policy. Limitations of the existing data are threefold. (1) They are limited to large turloughs. An educated guess based on the Gort lowlands study is that for each turlough $>10 \mathrm{ha}$, there are at least four other turloughs $<10$ ha. Hence, outside the Gort lowlands, this paper draws on data on $<20 \%$ of the Irish turloughs. (2) Studies were concentrated on the Gort lowlands, but this is just one specific hydrologeological setting. Other settings may have different hydrologies. (3) There is a lack of data for a range of ecological variables on turloughs in general. Working with typologies that are weakly supported by data with clear limitations thus seems more prone to error than working with a continuum concept that arises clearly from the same data. As a consequence, turlough conservation policy lacks the overview needed to implement conservation measures efficiently for a specific turlough, tends to implement a classic, site-based approach on turloughs already surveyed (large and spectacular), and seems in some cases, to restrict farming practices unnecessarily.

We believe that much additional research will be required to provide adequate guidance for turlough conservation. Specifically needed are comparative surveys of smaller turloughs and detailed multidisciplinary studies in other hydrogeological settings (in particular in the north-west of Ireland) examining within-turlough variation and inter-turlough connectivity. Data emerging from such studies might well alter the sketch laid out in this paper.

\section{ACKNOWLEDGMENTS}

We thank Roger Goodwillie and Jennings and O'Donovan engineering company for permission to use their data and Catherine Coxon for permission to use her data and for useful comments on an earlier draft. We gratefully acknowledge funding from the Irish Research Council for Science, Engineering and Technology, the Irish Higher Education Authority and the Marie Curie program of the EU. We thank one anonymous referee and Ned Euliss who commented extensively on the first submitted version.

\section{LITERATURE CITED}

Batzer, D. P., R. B. Rader, and S. A. Wissinger. 1999. Invertebrates in Freshwater Wetlands of North America. John Wiley \& Sons, New York, NY, USA.

Bond, K. G. M. 1997. Insect survey - Lepidoptera. p. 1-87, In Southern Water/Jennings and O'Donovan (ed.) An Investigation of the Flooding Problems in the Gort-Ardrahan Area of South Galway. Office of Public Works, Dublin, Republic of Ireland.

Clarke, K. R. 1993. Non-parametric multivariate analyses of changes in community structure. Australian Journal of Ecology 18:117-143.

Coxon, C. 1986. A study of the hydrology and geomorphology of turloughs. Ph.D. Thesis. Trinity College Dublin, Dublin, Republic of Ireland.

Coxon, C. 1987a. The spatial distribution of turloughs. Irish Geography 20:11-23.

Coxon, C. 1987b. An examination of the characteristics of turloughs, using multivariate statistical techniques. Irish Geography 20:24-42.

Coxon, C. and D. P. Drew. 1986. Groundwater flow in the lowland limestone aquifer of eastern Co. Mayo, western Ireland. p. 259-279, In K. Paterson and M. M. Sweeting (eds.) New Directions in Karst. Geo Books, Norwich, United Kingdom. 
Coxon, C. and D. P. Drew. 1998. Interaction of surface water and groundwater in Irish karst areas: implications for waterresource management. p. 161-168, In V. Brahana (ed.) Gambling with Groundwater - Physical, Chemical and Biological Aspects of Aquifer-Stream Relations. American Institute of Hydrology, Las Vegas, NV, USA.

Coxon, C. and D. P. Drew. 2000. Interdependence of groundwater and surface water in lowland karst areas of western Ireland: management issues arising from water and contaminant transfers. p. 81-88, In N. S. Robins and B. D. Misstear (eds.) Groundwater in the Celtic Regions: Studies in Hard Rock and Quaternary Hydrogeology. The Geological Society of London, London, United Kingdom.

Coxon, P. and C. E. Coxon. 1997. A pre-Pliocene or Pliocene land surface in County Galway, Ireland. p. 37-55, In $\mathrm{M}$. Widdowson (ed.) Palaeosurfaces: Recognition, Reconstruction and Palaeoenvironmental Interpretation. The Geological Society of London, London, United Kingdom.

Drew, D. P. 1976. Hydrogeology of the North Co. Galway South Co. Mayo lowland karst area, Western Ireland. Proceedings of the 6th International Congress of Spelaeology Olomouc, Czechoslovakia.

Drew, D. P. 1990. The hydrology of the Burren, County Clare. Irish Geography 23:69-89.

Drew, D. P. 1992. Water resource management and water tracing in a lowland karst aquifer. p. 221-225, In H. Hötzl and A. Werner (eds.) Tracer hydrology. Proceedings of the 6th international symposium on water tracing. Balkema, Amsterdam, The Netherlands.

Drew, D. P. 2003. The hydrology of the Burren and of Clare and Galway lowlands. p. 31-42, In G. Mullan (ed.) Caves of County Clare and South Galway. University of Bristol Spelaeological Society, Bristol, United Kingdom.

Drew, D. P. and D. Daly. 1993. Groundwater and Karstification in Mid-Galway, South Mayo and North Clare. Geological Survey of Ireland, Dublin, Republic of Ireland

Drew, D. P. and G. L. Jones. 2000. Post-Carboniferous preQuaternary karstification in Ireland. Proceedings of the Geologists' Association 111:345-353.

Duigan, C. A. 1988. The Cladocera (Crustacea) of Lough Rea and neighbouring waterbodies in Ireland. Bulletin of Irish Biogeographical Society 11:100-113.

Euliss, N. H. J., J. W. LaBaugh, L. H. Fredrickson, D. M. Mushet, M. K. Laubhan, G. A. Swanson, T. C. Winter, D. O Rosenberry, and R. D. Nelson. 2004. The wetland continuum: a conceptual framework for interpreting biological studies. Wetlands 24:448-458.

Ford, D. C. and P. W. Williams. 1989. Karst Geomorphology and Hydrology. Chapman \& Hall, London, United Kingdom

Foster, G. N., B. H. Nelson, D. T. Bilton, D. A. Lott, R. Merritt, R. S. Weyl, and M. D. Eyre. 1992. A classification and evaluation of Irish water beetle assemblages. Aquatic Conservation - Marine and Freshwater Ecosystems 2:185-208.

Good, J. A. and F. T. Butler. 2001. Turlough pastures as a habitat for staphylinidae and carabidae (coleoptera) in south-east Galway and north Clare, Ireland. Bulletin of Irish Biogeographical Society 25:74-94

Goodwillie, R. 1992. Turloughs over 10 ha. Vegetation survey and evaluation. National Parks and Wildlife Service, Office of Public Works, Dublin, Republic of Ireland.

Goodwillie, R. and J. D. Reynolds. 2003. Turloughs. p. 130-159, In M. L. Otte (ed.) Wetlands of Ireland. Distribution, Ecology, Uses and Economic value. University College Dublin, Dublin, Republic of Ireland

Haslam, S. M. 2003. Understanding Wetlands: Fen, Bog and, Marsh. Taylor \& Francis, London, United Kingdom.

Ivimey-Cook and M. C. F. Proctor. 1966. The plant communities of the Burren, Co. Clare. Proceedings of the Royal Irish Academy 64:211-301.

Jennings, J. N. 1985. Karst Geomorphology. Blackwell, Oxford, United Kingdom.
Johnston, P. and D. Peach. 1998. Groundwater modelling in the karst limestones of the Gort lowlands. Proceedings of the 19th annual groundwater seminar. Surface water and groundwater: a combined resource. International Association of Hydrogeologists (Irish Group), Portlaoise, Republic of Ireland.

Joyce, P. W. 1869. The Origin and History of Irish Names of Places. Exact facsimil reprint (1995) of the original. Edmund Burke, Dublin, Republic of Ireland.

Keddy, P. A. 2000. Wetland Ecology. Principles and Conservation. Cambridge University Press, Cambridge, United Kingdom.

Lott, D. A. 2003. An annotated list of wetland ground beetles (Carabidae) and rove beetles (Staphylinidae) found in the British Isles including a literature review of their ecology. English Nature, Peterborough, United Kingdom.Research Report 488.

MacGowran, B. 1985. Phytosociological and ecological studies on turloughs in the west of Ireland. Ph.D. Thesis. National University of Ireland, Galway, Republic of Ireland.

McCune, B. and J. B. Grace. 2002. Analysis of Ecological Communities. MjM Software Design, Gleneden Beach, OR, USA.

Nelson, B. and R. Thompson. 2004. The Natural History of Ireland's Dragonflies. The National Museums and Galleries of Northern Ireland, Belfast, Northern Ireland.

Ní Bhriain, B., M. Sheehy Skeffington, and M. Gormally. 2002. Conservation implications of land use practices on the plant and carabid beetle communities of two turloughs in $\mathrm{Co}$ Galway, Ireland. Biological Conservation 105:81-92.

O'Connell, M., J. B. Ryan, and B. A. MacGowran. 1984 Wetland Communities in Ireland: A phytosociological review. p. 303-364, In P. Moore (ed.) Wetland communities in Ireland: a Phytosociological Review. Academic Press, London, United Kingdom.

Reynolds, J. D. 1997. Invertebrate surveys of South-East Galway turloughs. p. 126-138, In Southern Water/Jennings and O'Donovan (ed.) An Investigation of the Flooding Problems in the Gort-Ardrahan Area of South Galway. Office of Public Works, Dublin, Republic of Ireland.

Sadler, J. P., D. Bell, and A. Fowles. 2004. The hydroecological controls and conservation value of beetles on exposed river sediments in England and Wales. Biological Conservation 118:41-56.

Simms, M. J. 2003a. The geology of the Burren and the Gort lowlands. p. 9-30, In G. Mullan (ed.) Caves of County Clare and South Galway. University of Bristol Spelaelogical Society, Bristol, United Kingdom.

Simms, M. J. 2003b. The geomorphological history of the Burren and the Gort lowlands. p. 15-30, In G. Mullan (ed.) Caves of County Clare and South Galway. University of Bristol Spelaeological Society, Bristol, United Kingdom.

Southern Water/Jennings and O'Donovan. 1997. An Investigation of the Flooding Problems in the Gort-Ardrahan Area of South Galway. Office of Public Works, Dublin, Republic of Ireland.

Sweeting, M. M. 1972. Karst Landforms. The Macmillan Press, London, United Kingdom.

Sweeting, M. M. 1973. Some aspects of karst hydrology. Geographical Journal 139:280-285.

Westlake, D. F., J. Kvêt, and A. Szczepanski. 1998. The Production Ecology of Wetlands. Cambridge University Press, Cambridge, United Kingdom.

Wheeler, B. D. 1980a. Plant communities of rich-fen systems in England and Wales: I. Introduction. Tall sedge and reed communities. Journal of Ecology 68:365-395.

Wheeler, B. D. 1980b. Plant communities of rich-fen systems in England and Wales: II. Communities of calcareous mires. Journal of Ecology 68:405-420.

Wheeler, B. D. 1980c. Plant communities of rich-fen systems in England and Wales: III. Fen meadow, fen grassland and fen woodland communities, and contact communities. Journal of Ecology 68:761-788. 
Wheeler, B. D. and M. C. F. Proctor. 2000. Ecological gradients, subdivisions and terminology of North-West European mires. Journal of Ecology 88:187-203.

Williams, P. W. 1970. Limestone morphology in Ireland. p. 105124, In N. Stephens and R. E. Glasscock (eds.) Irish Geographical Studies. Queens University, Belfast, Northern Ireland.
Williams, P. W. 1983. The role of the subcutaneous zone in karst hydrology. Journal of Hydrology 61:45-67.

Manuscript received 29 June 2005; revision received 27 January 2006; accepted 30 May 2006. 
Appendix. Original variables of both datasets (numbered as in Table 2) and Pearson (r) and Kendall $(\tau)$ correlations with ordination axes. Determination coefficients $\left(\mathrm{r}^{2}>0.2\right.$ are in bold.

\begin{tabular}{|c|c|c|c|c|c|c|c|c|c|c|}
\hline \multirow{2}{*}{\multicolumn{2}{|c|}{ Coeff. of determination $(\%)$ : }} & \multicolumn{9}{|c|}{ Gort dataset } \\
\hline & & \multicolumn{3}{|c|}{22.5} & \multicolumn{3}{|c|}{50.2} & \multicolumn{3}{|c|}{14.1} \\
\hline \multirow{2}{*}{\multicolumn{2}{|c|}{ Axis: }} & \multicolumn{3}{|c|}{1} & \multicolumn{3}{|c|}{2} & \multicolumn{3}{|c|}{3} \\
\hline & & $\mathrm{r}$ & $r^{2}$ & $\tau$ & $\mathrm{r}$ & $r^{2}$ & $\tau$ & $\mathrm{r}$ & $r^{2}$ & $\tau$ \\
\hline 1 & Conductivity &,- 415 &, 172 &,- 298 & ,583 & ,339 & ,391 & ,339 &, 115 & ,221 \\
\hline 2 & Alkalinity &,- 384 & 147 &,- 332 & ,709 &, 503 &, 530 & 140 & 019 &, 125 \\
\hline 3 & Water level fluctuation & , 109 &, 012 &, 082 &,- 435 &, 189 &,- 350 & ,428 &, 184 & ,364 \\
\hline 4 & Response to rainfall &, 134 &, 018 & ,095 &,- 607 & ,369 &,- 473 &,- 058 &, 003 &, 005 \\
\hline 5 & Summer water & ,837 & ,700 & ,700 & ,297 & ,088 & ,289 &,- 102 &, 010 &,- 068 \\
\hline 6 & Date of draining & 669 & ,448 & ,519 & ,492 & ,242 & ,433 &,- 080 & ,006 &,- 078 \\
\hline 7 & Marl &, 160 &, 026 & ,126 &, 761 & ,579 &, 589 &,- 393 & 155 &,- 301 \\
\hline 8 & Drift thickness &,- 314 & ,099 &,- 229 &,- 024 &, 001 &,- 017 & ,766 &, 586 &, 656 \\
\hline 9 & Nutrient status &,- 351 &, 123 &,- 257 &,- 769 &, 592 &,- 618 & ,478 & ,228 &, 372 \\
\hline 10 & Littorella uniflora & ,494 & ,244 & ,409 &, 127 &, 016 & ,087 &,- 387 &, 150 &,- 334 \\
\hline \multirow[t]{5}{*}{11} & Reedbeds & ,623 & ,388 & ,514 &, 585 & ,342 & ,507 &,- 070 &, 005 &,- 035 \\
\hline & & \multicolumn{9}{|c|}{ Coxon/Goodwillie dataset } \\
\hline & Coeff. of determination (\%): & \multicolumn{3}{|c|}{18,5} & \multicolumn{3}{|c|}{20,5} & \multicolumn{3}{|c|}{40,3} \\
\hline & \multirow[t]{2}{*}{ Axis: } & \multicolumn{3}{|c|}{1} & \multicolumn{3}{|c|}{2} & \multicolumn{3}{|c|}{3} \\
\hline & & $\mathrm{r}$ & r-sq & $\tau$ & $\mathrm{r}$ & r-sq & $\tau$ & $\mathrm{r}$ & r-sq & $\tau$ \\
\hline 1 & Floor & ,273 &, 074 & ,190 &,- 326 &, 106 &,- 274 &,- 563 & ,317 &,- 390 \\
\hline 2 & Slopes &,- 109 &, 012 &,- 090 &,- 072 &, 005 &, 028 &,- 502 & ,252 &,- 388 \\
\hline 3 & Depth of flooding &,- 218 & 047 &,- 226 &,- 357 & 128 &,- 215 &,- 598 & ,358 &,- 371 \\
\hline 4 & Irregularity index &,- 128 & 016 &,- 093 &,- 163 & 027 &,- 027 &, 586 & ,343 &, 429 \\
\hline 5 & Elongation index & ,355 &, 126 &, 219 &,- 059 &, 004 &,- 013 & ,418 & 174 & 340 \\
\hline 6 & Marl only &,- 660 & ,435 &,- 552 &, 057 &, 003 &, 065 & , 190 & ,036 & 124 \\
\hline 7 & Peat or peat/marl &,- 550 & ,303 &,- 451 &, 431 & 186 & ,365 &, 573 & ,328 &, 504 \\
\hline 8 & Mineral deposits & ,660 & ,435 &, 541 &,- 271 & 073 &,- 212 &,- 517 & 267 &,- 383 \\
\hline 9 & Extent of limestone outcrop &,- 208 & 043 &,- 162 &,- 427 & 182 &,- 398 & ,406 & 165 & ,248 \\
\hline 10 & Level above ordnance datum &, 107 & 012 &, 104 &, 704 & ,495 &, 579 &,- 239 &, 057 &,- 202 \\
\hline 12 & Catchment area/ turlough area &,- 080 &, 006 &,- 002 & ,486 & 236 &,- 210 &,- 044 &, 002 &,- 037 \\
\hline 13 & Alkalinity &,- 424 &, 179 &,- 360 &,- 078 &, 006 &,- 096 &, 534 & ,286 & ,323 \\
\hline 14 & $\%$ grass &, 645 & ,416 & ,398 &,- 557 & ,310 &,- 392 &,- 539 & ,290 &,- 406 \\
\hline 15 & $\%$ sedge &,- 143 &, 020 &,- 075 &, 554 & ,307 & ,412 &, 305 & 093 &, 228 \\
\hline 16 & $\%$ aquatic &,- 695 & ,483 &,- 459 & , 191 & ,036 & , 141 & ,406 &, 165 & ,304 \\
\hline
\end{tabular}

